\title{
THE PERFORMANCE EFFICIENCY OF CAYENNE PEPPER SUPPLY CHAIN IN WONGSOREJO DISTRICT BANYUWANGI REGENCY
}

\author{
Annastia Loh Jayanti ${ }^{*}$, Kanthi Pangestuning Prapti*), and Ahmad Hadi ${ }^{*}$ \\ *) Agrotechnology Program, Faculty of Agriculture and Fisheries, Universitas 17 Agustus 1945 Banyuwangi \\ Jl. Adi Sucipto 26 Banyuwangi 68416
}

\begin{abstract}
Banyuwangi Regency becomes one of the cayenne pepper suppliers to the national market, and Wongsorejo District is the largest cayenne pepper centre. The supply, continuity, quality, and price of cayenne pepper in Wongsorejo District shows different values over time can hamper the cayenne pepper agribusiness supply chain's performance. This study aimed to map the cayenne pepper supply chain's flow and measure the cayenne pepper supply chain's performance in Wongsorejo District. The research method uses descriptive-qualitative analysis to map the supply chain flow of cayenne pepper. The Hayami added value analysis method to measure the cayenne pepper supply chain's performance. The results showed that the supply chain of cayenne pepper in Wongsorejo District consisted of Agricultural Kiosks and the Government as suppliers; farmers as producers; collector traders, wholesalers, retailers and market traders distributors; as well as consumers. Farmers got a value-added of Rp5.845,83/ $\mathrm{kg}$, wholesaler of Rp12.849,48/ kg, and retailers of Rp5.323,74/ kg with a marketing margin of Rp18.750,83/kg. The supply chain of cayenne pepper in Wongsorejo District was classified as efficient because the profits share was greater than the costs shared.
\end{abstract}

Keywords: cayenne pepper, efficiency, hayami, supply chain

\begin{abstract}
Abstrak: Kabupaten Banyuwangi yang berada di Jawa Timur merupakan salah satu sentra cabai rawit terbesar sekaligus sebagai pemasok kebutuhan pasar nasional dan Wongsorejo merupakan sentra cabai rawit terbesar di Banyuwangi. Jumlah pasokan, kontinuitas, kualitas, dan harga cabai rawit di Kecamatan Wongsorejo menunjukkan nilai yang tidak sama dalam setiap waktu. Hal ini dapat menghambat kinerja supply chain agribisnis cabai rawit yang ada di Kecamatan Wongsorejo. Tujuan penelitian ini adalah untuk mengetahui aliran supply chain cabai rawit di Kecamatan Wongsorejo Kabupaten Banyuwangi, mengukur kinerja supply chain cabai rawit di Kecamatan Wongsorejo. Metode penelitian menggunakan analisis deskriptif-kualitatif untuk memetakan aliran rantai pasok cabai rawit, dan metode analisis nilai tambah Hayami untuk mengukur kinerja rantai pasok cabai rawit. Hasil peneitian menunjukkan bahwa rantai pasok cabai rawit di Kecamatan Wongsorejo terdiri dari Kios Pertanian dan Pemerintah sebagai supplier; petani sebagai produsen; Pedagang pengumpul, pedagang besar, pedagang pengecer, dan pedagang pasar sebagai distributor; serta konsumen. Analisis nilai tambah menunjukkan bahwa petani mendapatkan nilai tambah sebesar Rp5.845,83/kg, pedagang pengepul sebesar Rp12.849,48/kg, dan pedagang pengecer sebesar Rp5.323,74/kg dengan margin pemasaran dari petani hingga ke konsumen sebesar Rp18.750,83/kg. Rantai pasok cabai rawit di Kecamatan Wongsorejo tergolong efisien, karena share keuntungan lebih besar dibandingkan dengan share biaya.
\end{abstract}

Kata kunci: cabai rawit, efisiensi, hayami, kinerja, rantai pasok

\footnotetext{
${ }^{1}$ Corresponding author:

Email: annastiajayanti@untag-banyuwangi.ac.id
} 


\section{INTRODUCTION}

Cayenne pepper is a horticultural product that has high economic value and profitable business opportunities for cultivation. The national supply of chillies is approximately 30 percent supplied from East Java. Banyuwangi is a district in East Java, one of the largest cayenne pepper centers and a supplier to the national market needs, and Wongsorejo is the largest cayenne pepper district in Banyuwangi (TabloidSinarTani. com, 2018). According to the Banyuwangi Regency Agriculture Office, the harvested area for cayenne pepper from 2014 to 2018 shows increasing value, followed by increased production from 2013 to 2018 . In 2014, cayenne pepper production was 20,614 tons with a harvest area of 2,924 ha, and in 2018 amounted to 28,691 tons with a harvest area of 3,676 ha.

The supply, continuity, quality, and price of cayenne pepper in Wongsorejo District shows different values over time that can hamper the cayenne pepper agribusiness supply chain's performance in Wongsorejo District. Supply Chain is a process and production activity starting from raw materials obtained from suppliers, the process of adding value that converts raw materials into finished goods, the process of storing goods inventory until the process of sending the finished goods to retailers and consumers (Pujawan and Mahendrawathi, 2017). The main purpose of the supply chain is to meet consumer needs and generate profits. The supply chain places more emphasis on all activities to meet consumer needs. There are flow and transformation of goods from raw materials to end consumers and accompanied by information and money flow.

Data from the Ministry of Trade shows that cayenne pepper's price has increased significantly only in certain months. The national chili price has been unstable during 2019. This condition is indicated by the high coefficient of variation of monthly costs for February 2018 to February 2019, namely 16.78\% for red chilies and $19.87 \%$ for cayenne pepper. Specifically for February 2019, the national average daily price for household chilies decreased by $2.14 \%$ for red chilies and increased by $2.11 \%$ for cayenne pepper (Kementerian Perdagangan Republik Indonesia, 2019).

The supply flow of this commodity influences the price fluctuation of cayenne pepper. It cannot be predicted because it is related to natural and environmental factors that cannot be controlled as a whole. One of the conditions that occurred in 2019, as conveyed by the Director-General of Domestic Trade of the Ministry, was that the harvest damaged in production centers such as Banyuwangi, Lumajang and Jember. The cause is the increase in chilli plants' disease and the condition of water shortages in November-December 2019, which has triggered a continued reduction in chili production centers in many regions, and prices continue to rise.

Price fluctuations in the retail market are caused not only by factors that affect the supply side. It can be explained that sometimes the price balance occurs when the quantity supplied is relatively much less than the quantity demanded. This will cause the price to be very high. Likewise, the opposite happens so that prices are meager. The supply side shows that the supply process (production and distribution) of cayenne pepper is not fully controlled by the farmers (Sondakh and Rengu, 2017).

Fluctuations in production levels and prices can cause performance along the supply chain to fluctuate. The role of stakeholders in managing the flow of goods, information and money in each supply chain of cayenne pepper agribusiness will affect the efficiency and effectiveness of performance along the supply chain. Kurniawan et al. (2014) revealed that the commodity supply chain is efficient when viewed from: a) The value of the share of profits is greater when compared to the allocation of costs and; b) The share value of the price of each link is considered fair or proportionally following the function performed.

The fluctuations of chili prices show the importance of maintaining the supply of cayenne pepper because this can impact food commodity prices' stability. The integration of the supply chain of cayenne pepper from upstream to downstream must be supported by adequate infrastructure and institutions to increase the cayenne pepper commodity's productivity (Adhitya Wardhono et al. 2020). Supply chain performance measurement will provide an excellent opportunity to improve and develop supply chain management in all industries (Bolstorff, 2003 in Sartika Lestari, 2016). This study aimed to determine the flow of the cayenne pepper supply chain in Wongsorejo District, Banyuwangi Regency, and to measure the performance of the cayenne pepper supply chain in Wongsorejo District. 


\section{METHODS}

The research object was determined by the purposive method, which was carried out in Wongsorejo District, which is in the northern part of Banyuwangi Regency, which is one of the cayenne pepper centers. The research method used is descriptive-analytic, namely by raising the research object related to data, facts, and phenomena that exist when the research takes place within the scope of the supply chain.

Primary data collection techniques are carried out by: Field observations, by directly observing activities that occur along the supply chain; In-depth interviews to obtain comprehensive information regarding the processes that take place along the supply chain; Focus group discussion (FGD) was carried out to gain understanding in the formulation of a strategy to improve the performance of the cayenne pepper supply chain. Secondary data were collected by conducting literature studies.
The flow of the cayenne pepper supply chain is analyzed using descriptive-qualitative methods by taking into account the opinions of experts and resource persons. The performance efficiency of the cayenne pepper supply chain is analyzed based on the added value obtained along the supply chain using the Hayami added value method (Table 1).

Hayami's method (Hayami et al. 1987), in calculating the added value of combining added value methods for processing and added value for marketing. The original Hayami Method, the conversion factor, labor coefficient, product value, added value, value added ratio, employee benefits, contribution of other inputs, as well as the level of profit and margin can be determined. The Hayami method is better because it can be used for a series of companies involved in the supply chain. With this method it can be seen the amount of added value, output value, and productivity. It can also be seen the amount of remuneration for the owners of production factors (Hidayat et al. 2012).

Table 1 . The procedure for calculating the added value of the Hayami method

\begin{tabular}{lcc}
\hline Variable & Value & Unit \\
\hline Output & $\mathrm{A}$ & Ton/year \\
Raw material & $\mathrm{B}$ & Ton/year \\
Labor & $\mathrm{C}$ & Man-day/year \\
Conversion Factor & $\mathrm{D}=\mathrm{A} / \mathrm{B}$ & Ton/ year \\
Direct Labor Coefficient & $\mathrm{E}=\mathrm{C} / \mathrm{B}$ & Man-day $/$ ton \\
Output price & $\mathrm{F}$ & $\mathrm{Rp} /$ ton \\
Average Wage of Labor & $\mathrm{G}$ & $\mathrm{Rp} / \mathrm{Man}$-day \\
Raw material prices & $\mathrm{H}$ & $\mathrm{Rp} /$ ton \\
Other Input Contributions & $\mathrm{I}$ & $\mathrm{Rp} /$ ton \\
Output Value & $\mathrm{J}=\mathrm{DxF}$ & $\mathrm{Rp} /$ ton \\
Value-added & $\mathrm{K}=\mathrm{J}-\mathrm{H}-\mathrm{I}$ & $\mathrm{Rp} /$ ton \\
Value Added Ratio & $\mathrm{L}(\%)=(\mathrm{K} / \mathrm{J}) \times 100 \%$ & $\%$ \\
Employee Benefits & $\mathrm{M}=\mathrm{E} \times \mathrm{G}$ & $\mathrm{Rp} /$ ton \\
Labor Section & $\mathrm{N}(\%)=(\mathrm{M} / \mathrm{K}) \times 100 \%$ & $\%$ \\
Advantage & $\mathrm{O}=\mathrm{K}-\mathrm{M}$ & $\mathrm{Rp} /$ ton \\
Profit Rate & $\mathrm{P}(\%)=(\mathrm{O} / \mathrm{K}) \times 100 \%$ & $\%$ \\
Margin & $\mathrm{Q}=\mathrm{J}-\mathrm{H}$ & $\mathrm{Rp} /$ ton \\
Direct Labor Income & $\mathrm{R}(\%)=(\mathrm{M} / \mathrm{Q} \times 100 \%$ & $\%$ \\
Other Input Contributions & $\mathrm{S}(\%)=(\mathrm{I} / \mathrm{Q}) \times 100 \%$ & $\%$ \\
Company Profits & $\mathrm{T}(\%)=(\mathrm{O} / \mathrm{Q}) \times 100 \%$ & $\%$ \\
\hline
\end{tabular}




\section{RESULTS}

\section{The Supply Chain of Cayenne Pepper in Wongsorejo District, Banyuwangi Regency}

Supply chain management is a flow network management that delivers a product to the final producer. The supply chain defined as companies network that works together to create and deliver a product to the end consumer. These companies include suppliers, factories, distributors, shops or retail, and supporting companies such as logistics or shipping service companies. Three flows must manage in the supply chain: the flow of goods, money flow, and information flow (Pujawan, 2010).

The chili agribusiness in Wongsorejo District, which supply chain activity actors carry out, consists of suppliers, producers, distributors, and consumers. Suppliers consist of agricultural stalls, farmers, and the government. Farmers as producers of cayenne pepper. Distributors comprised of traders, wholesalers, retailers, and traders. The last chain to go to is the consumer. An overview of the flow of cayenne pepper supply chain in Wongsorejo District, Banyuwangi Regency is shown in Figure 1.

An overview of the cayenne pepper supply chain flow in Wongsorejo District, Banyuwangi Regency, is as follows:

Product flow

The product flow is the flow of cayenne pepper to the hands of consumers. This flow is unidirectional, starting from the supplier to the farmer, which consumers will eventually accept through the distributor. Suppliers provide farmers' input in producing (cultivating) cayenne pepper, including seeds, fertilizers, and pesticides. Input providers consist of agricultural kiosks and the government. Farmers buy seeds, fertilizers, and pesticides at farm stalls. The subsidized fertilizer purchase adjusted to the Group Needs Definitive Plan (RDKK) for each farmer group. The government's role as a supplier is that the government provides fertilizer assistance and production equipment.

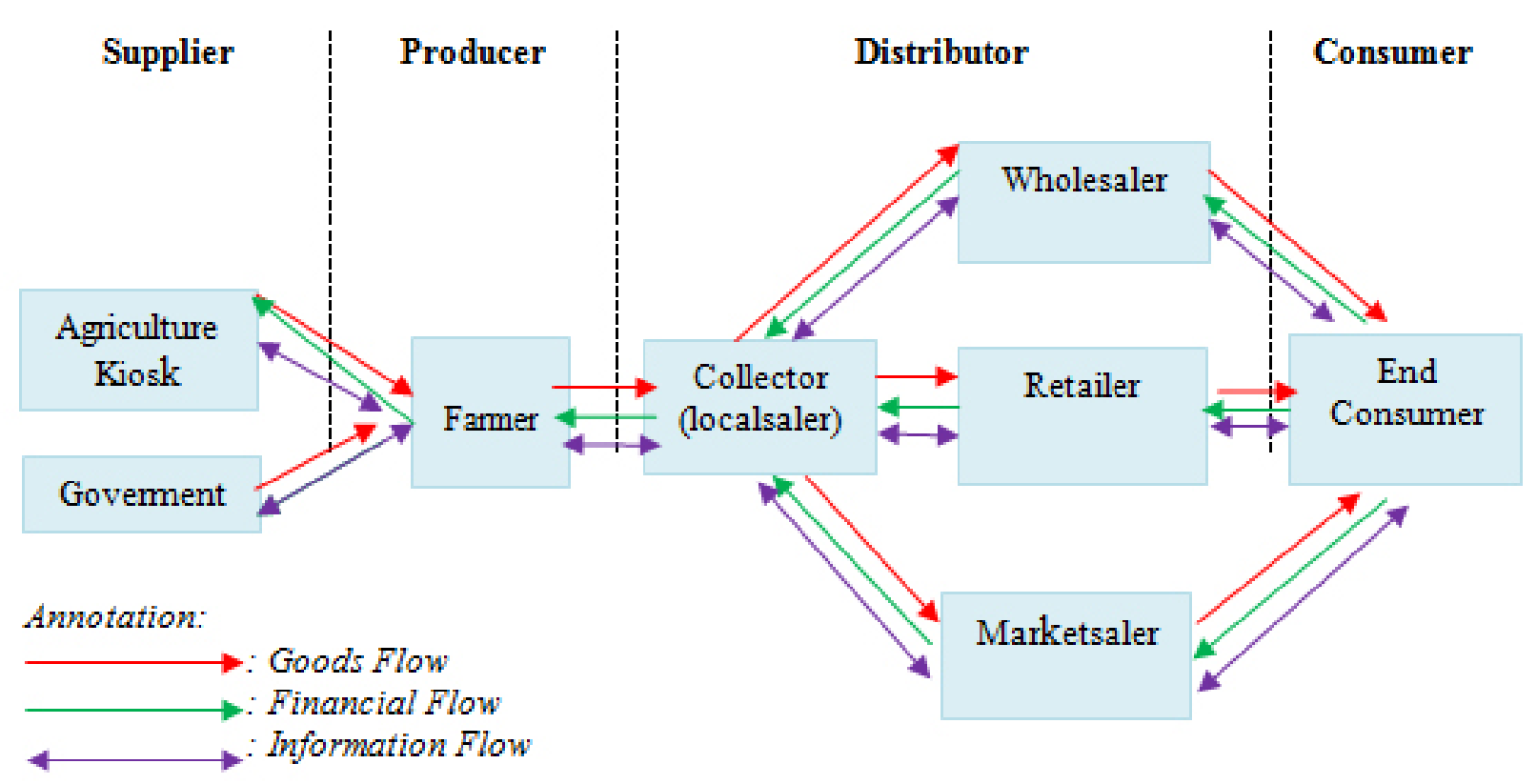

Figure 1. The flow of cayenne pepper supply chain activities in Wongsorejo District 
Farmers have a role as cayenne pepper producers because the cultivation process consists of land cultivation, planting, fertilizing, irrigation, controlling pests and diseases, and harvesting. The distributor acts as an intermediary entity between a product's producer and another entity in the distribution channel or supply chain. Distributors consist of collectors, wholesalers, retailers, and traditional markets. Collector traders tasked with collecting cayenne pepper from farmers to be distributed to wholesalers, retailers, and traditional markets to reach the final consumer.

\section{Financial Flow}

Financial flow is a picture of the flow of money starting from consumers flowing in each link in the chain, which will eventually reach the producers to be used as production costs. This flow of funds is unidirectional, meaning that funds generated from exchanges with products purchased by consumers by passing through several links, which producers will eventually accept in exchange for the products they produce. The flow of funds flows from downstream to upstream, starting from consumers, distributors, producers, and suppliers.

Funding is an essential requirement for all actors involved in the supply chain of red chili with a structured market orientation, especially farmers. The availability of financing in the supply chain currently depends only on the internal actors in the chain itself (Karyani et al. 2015).

Consumers will buy cayenne pepper from wholesalers, retailers and traditional markets, and supermarkets. Wholesalers, retailers, and traditional markets buy cayenne pepper from collectors obtained directly from farmers. The proceeds from the funds received by farmers from collectors used to purchase suppliers' plant production needs.

\section{Information Flow}

Information flow is a description of the flow of information needed in the cayenne pepper supply chain. The flow of information flows from upstream to downstream and vice versa, namely from suppliers to consumers and from consumers to suppliers. The flow of information from upstream to downstream starts from suppliers who provided information to farmers about the types of fertilizers, pesticides, seeds, and technology used by farmers in cultivating cayenne pepper. Farmers as producers provide distributors with information about the type, quality, and quantity of cayenne pepper produced, and then the distributor delivers it to consumers.

The flow of information from downstream to upstream starts from consumers providing information to distributors about the quality and quantity of cayenne pepper desired. Distributors convey this information to farmers as producers. Farmers provide information to suppliers about the need for seeds, fertilizers, and pesticides needed, both in type and quantity.

The supply chain of cayenne pepper agribusiness in Wongsorejo Subdistrict, Banyuwangi Regency starts from suppliers of agricultural production facilities (saprotan) as providers of raw materials for production, then farmers as producers who carry out cultivation activities, followed by a marketing chain consisting of traders of collectors to distributing fresh cayenne pepper products to the consumer. Measurement of the supply chain's performance of cayenne pepper is to calculate all input requirements used in the production process and the revenues obtained after the product transferred to the next supply chain.

The factors that influence supply chain performance are 1. Inventory goods are influenced by production, price, quality, production capacity, product differentiation; 2. Transportation is affected by costs and equipment; 3. Facilities are affected by facility location, facility allocation, and market allocation; 4. Information influenced by information technology and supply chain institutions (Ndiba et al. 2016).

\section{The results of supply chain analysis on cayenne pepper agribusiness in Wongsorejo District, Banyuwangi Regency}

\section{Chain structure}

There are six chains members involved in the cayenne pepper supply chain mechanism in Wogsorejo District, namely:

1. Cayenne pepper farmer (The cayenne pepper farmer is the chain that acts as the primary producer in the cayenne pepper supply chain in Wongsorejo District).

2. Collector traders (Collector traders are the first marketing distribution agencies involved in the distribution of cayenne pepper in Wongsorejo 
District).

2. Wholesalers (Wholesalers are institutions that play a role in meeting the needs outside the Banyuwangi Regency area, such as Jember, Denpasar, Surabaya, Bandung, Yogyakarta, Jakarta).

3. Retailers (The retailer is a marketing agency that deals directly with cayenne pepper consumers).

4. Market traders (Market traders are one of the links or marketing agencies that distribute cayenne pepper in large quantities in the Banyuwangi Regency).

5. Consumers (Consumers are the last link in the chain that uses cayenne pepper to meet their own needs).

Production process

The cayenne pepper production process starts from the provision of inputs, the cultivation process, and harvesting. The provision of information needed in cayenne pepper production consists of providing land, labor, equipment, seeds, fertilizers, pesticides, and capital. Part of the land owned by farmers is their land. Most of the production activities carried out by farmers themselves, assisted by family labor. Some of them use external labor only to cultivate the land-procurement of seeds, fertilizers, and pesticides through agricultural stalls. Meanwhile, capital consists of independent capital, loans from banks, and collectors' loans because the harvest sold to them.

Most of the farmers have implemented GAP / SOP for cayenne pepper cultivation. In the cultivation process, farmers use chemical and semi-organic cultivation systems. Some of the cayenne pepper farmers in the Wongsorejo District use chemical fertilizers and pesticides in their cultivation process, but using them is still within the applicable regulatory limits. Most of the farmers have implemented a semi-organic cultivation system, which collaborates between chemical and organic fertilizers/pesticides. The harvest area for cayenne pepper in Wongsorejo District is 2,340 ha with an average production yield of 5 tonnes/ha.

\section{Distribution}

Distribution and marketing activities are important aspects of cayenne pepper agribusiness. The right distribution and marketing channels will be more efficient. The distribution process will indirectly form a channel that connects the links involved in the cayenne pepper supply chain in Wongsorejo District. The distribution pattern of cayenne pepper in Wongsorejo
District generally follows the distribution pattern of storage with package carrier delivery, where cayenne pepper products reach consumers through distributor services. The distribution channels of cayenne pepper in Wongsorejo District consist of 5, namely:

1. Farmers $\rightarrow$ collectors $\rightarrow$ wholesalers $\rightarrow$ retailers $\rightarrow$ consumers

2. Farmers $\rightarrow$ wholesalers $\rightarrow$ retailers $\rightarrow$ consumers

3. Farmers $\rightarrow$ traders $\rightarrow$ wholesalers $\rightarrow$ market traders $\rightarrow$ consumers

4. Farmers $\rightarrow$ traders $\rightarrow$ market traders $\rightarrow$ retailers $\rightarrow$ consumers

5. Farmers $\rightarrow$ traders $\rightarrow$ market traders $\rightarrow$ consumers

Based on the distribution channel above, the cayenne pepper distribution chain in Wongsorejo District is quite long. The longer the distribution channel, the more ineffective the distribution channel's efficiency level is; this is because the costs incurred are more and more because the profits obtained in the marketing chain are increasing.

\section{Marketing}

Cayenne pepper farmers in Wongsorejo District do not have adequate market information, market demand, and price information. This is an opportunity for collectors/ traders to reduce the price offered to farmers so that farmers' bargaining position is low. The market structure is in an imperfectly competitive market where traders have more control over information about prices, costs, and market conditions. Lack of farmers' information on market demand could be one of the factors causing price fluctuations.

\section{Institution}

The farmer level's institutional role is needed to ensure the balance of chili prices, both at the farm level and at the end consumer level. Institutions involved in the supply chain activities of cayenne pepper in Wongsorejo District are:

\section{Department of Agriculture}

The Department of Agriculture plays a role in the formation of farmer groups/Gapoktan. The Banyuwangi Regency Agriculture Office through the Wongsorejo District Agricultural Extension Center has provided assistance and counseling, held GAP/SOP field schools, provided facility assistance, and technology 
transfer. The assistance provided by the government only reaches a small number of farmer groups.

2. The cayenne pepper farmer group/farmer group association

The cayenne pepper farmer group/farmer group association in the Wongsorejo sub-district acts as a media for joint learning and technology transfer. Farmer groups / Gapoktan cannot access the market in groups. Wongsorejo sub-district has 134 farmer groups spread across 12 villages.

\section{Financial Institution}

Financial institutions play a role in providing capital loans to farmers. Several formal financial institutions provide capital loans to cayenne pepper farmers in Wongsorejo District, including BRI, Bank Mandiri, KSP, and BPR. Apart from legal institutions, there are non-formal financial institutions that provide capital loans, namely agricultural kiosks and traders. Agricultural kiosks provide loans in the form of fertilizers and pesticides with a payment system made after harvest. Traders provide capital loans because the crop sold to them at a price determined by the trader.

\section{Marketing Institution}

The marketing agency involved in the cayenne pepper supply chain in Wongsorejo District is a collector trader. Collector traders buy cayenne pepper from several farmers. They estimate the total value of cayenne pepper by estimating the harvest multiplied by the expected price at harvest.

\section{Supply Chain Performance for Cayenne Pepper in Wongsorejo District, Banyuwangi Regency}

Sustainability is a keyword in the supply chain. Each link in the chain is a stakeholder who has an interest and influence on the supply chain's sustainability. The main objective of the supply chain flow is to benefit each actor/chain, but for sustainability to be maintained, must also be fulfilled social and environmental interests. This is in line with the Triple Bottom Line concept that each stakeholder must pay attention to 3 (three) aspects of sustainability, namely economic sustainability (profit), social sustainability (people), environmental sustainability (planet) (Felisia and Limijaya, 2014).
Economic sustainability in the supply chain achieved if there is added value economically at each link of the chain involved. One of the problems in the supply chain of cayenne pepper in the Banyuwangi Regency is that there is no standard price from the authorities so that the cost of cayenne pepper can fluctuate at any time without control. The prevailing price is the market price, where the marketing actors who are directly related to farmers as producers are traders of collectors. The following is data on the average cost of cayenne pepper that applies during 2019, based on data collection from respondents consisting of farmers, collectors, and retailers (Table 2).

Analysis of the added value economically in the supply chain of cayenne pepper was carried out using the modified Hayami method. The use of the Hayami Method has advantages, among others, being able to determine the amount of added value for the processing of agricultural products and being able to find out several output values such as the amount of remuneration for production factors (labor, other input contributions, and profits). Based on the results of data collection along the supply chain, input, output, and added value obtained by each actor in the cayenne pepper production chain are as follows (Table 3 ).

Based on the analysis of actors' added value in the supply chain of cayenne pepper in Wongsorejo District, Banyuwangi Regency. There are several marketing agencies involved that get to the hands of consumers. The longer the marketing chain, the higher the price received by consumers when compared to the price at the farm level. The cayenne pepper commodity sold by farmers to the next marketing chain and reaches consumers in the same form (no processing). The analysis of the added value of cayenne pepper shows that the average added value received by farmers is $\mathrm{Rp} 5,845.83 / \mathrm{kg}$ or $97.43 \%$, reduced by labor costs, so that the profit rate is $\mathrm{Rp} 3,595.83 / \mathrm{kg}(61.51 \%)$.

Each actor in the supply chain carries out a specific function that generates added value, hoping to get a proportional reward according to the quality of services provided for the product (Qashiratuttarafi et al. 2018). Qashiratuttarafi et al. (2018) continued can measure that added value through processing value or the process of increasing product prices so that the purpose of measuring added value is to see how much part of the remuneration is received. By the process of changing from input to output. 
Table 2. The average price of cayenne pepper during 2019 (Rupiahs)

\begin{tabular}{lccc}
\hline & Month & \multicolumn{2}{c}{ Price (Rp) } \\
\cline { 2 - 4 } & Farmer & Collectors & Retailer \\
\hline January & 9,840 & 20,500 & 25,000 \\
February & 4,560 & 9,500 & 12,000 \\
March & 5,280 & 11,000 & 18,000 \\
April & 5,760 & 12,000 & 17,000 \\
May & 4,560 & 9,500 & 17,000 \\
June & 4,560 & 9,500 & 12,000 \\
July & 26,160 & 54,500 & 60,000 \\
August & 34,320 & 71,500 & 80,000 \\
September & 19,920 & 41,500 & 48,000 \\
October & 12,000 & 25,000 & 28,000 \\
November & 9,120 & 19,000 & 30,000 \\
December & 13,920 & 29,000 & 32,000 \\
\hline Average & 12,500 & $26,041.67$ & $31,583.33$ \\
\hline
\end{tabular}

Table 3. Value-added supply chain actors of cayenne pepper in Wongsorejo District Banyuwangi Regency

\begin{tabular}{|c|c|c|c|}
\hline & Farmers & $\begin{array}{l}\text { Collector traders } \\
\text { (middlemen) }\end{array}$ & Retail Traders \\
\hline \multicolumn{4}{|l|}{ I. Output, Input, and Price } \\
\hline Output (sales volume) & 6,000 & 5,340 & $4,752.60$ \\
\hline Input ( $\mathrm{kg}$ / production process) & 0.20 & 6,000 & 5,340 \\
\hline Direct Labor & 90 & 90 & 30 \\
\hline Conversion Factor & 30,000 & 0.89 & 0.89 \\
\hline Coefficient of Q. Direct Employment & 450 & 0.02 & 0.01 \\
\hline Output price (IDR / kg) & $13,012.50$ & $26,041.67$ & $31,583.33$ \\
\hline \multicolumn{4}{|l|}{ II. Acceptance and Value Added } \\
\hline Labor wages (Rp / Man-day) & 30,000 & 90,000 & 90,000 \\
\hline Price of raw materials $(\mathrm{Rp} / \mathrm{kg})$ & $7.166,67$ & $13,012.50$ & $26,041.67$ \\
\hline Other input contributions (IDR / kg) & & 179.69 & 217.93 \\
\hline Output value (Rp) & $78,075,000$ & $139,062,500$ & $150,102,950$ \\
\hline a. Added value (IDR / kg) & $5,845.83$ & $12,849.48$ & $5,323.74$ \\
\hline b. Value added ratio (\%) & 97.43 & 240.63 & 112.02 \\
\hline a. Labor income (IDR / kg) & 2,250 & 1,350 & 505.62 \\
\hline b. Share of labor $(\%)$ & 38.49 & 10.51 & 9.50 \\
\hline a. Profit (Rp / kg) & $3,595.83$ & $11,499.48$ & $4,818.12$ \\
\hline b. Profit rate (\%) & 61.51 & 89.49 & 90.50 \\
\hline III. Remuneration for production factors & $5,845.83$ & $13,029.17$ & $5,541.67$ \\
\hline Margin (IDR / kg) & 38.49 & 10.36 & 9.12 \\
\hline a. Labor income (\%) & - & 1.38 & 3.93 \\
\hline b. Contribution of other inputs (\%) & 61.51 & 88.26 & 86.94 \\
\hline
\end{tabular}


Collector traders (middlemen) are the first marketing institutions to buy products directly from farmers (producers). At the level of wholesaler traders, the resulting value-added ratio is much higher than that of farmers, which is $240.63 \%$, so that the average profit level of these traders is $89.49 \%$. This is due to the higher average selling price of cayenne pepper products (Rp26,041/kg) compared to the average price purchased from farmers, Rp13,012.50. The market determines the selling price of farmers' cayenne pepper. This causes farmers to have a low bargaining value because they cannot decide on their prices and depend on the prevailing market price. This is reinforced by Adhitya Wardhono et al. (2020), that farmers do not have information about prices, only based on speculation and previous price information. If the partners can provide price certainty, the farmers will be more interested.

The role of collector traders is very large in the supply chain. This is reinforced by Saragih (2017) opinion, which states that the partnership process only occurs between collector traders (middlemen) and large collectors. Middlemen who get products from farmers will only sell to large collectors who become partners. Middlemen who are partners of large collectors usually receive loan assistance without interest from large collectors when making purchases from farmers. All agreements between supply chain members are informal. The trust among supply chain members is also stronger if the partner supply chain members can always fulfil the contracts that have been made.

Retail traders get cayenne pepper products that traders distribute. The added value at the retail merchant level is not much different from that of the farmers, $\mathrm{Rp5}, 541.67$, but it has a much larger value-added ratio, namely $112.02 \%$. The amount of profit obtained by retailers is $\mathrm{Rp} 4,818.12 / \mathrm{kg}$ or equivalent to $90.50 \%$. Collectors and retailers can get a much bigger profit than farmers, one of which is by saving labor costs. Farmers as producers incur significant costs for the production process, $38.49 \%$, while collectors only spend $10.51 \%$ and retail traders $9.50 \%$ of the total costs. Collectors and retailers incur costs for other input contributions such as transportation and packaging. However, the percentage is very small, namely $1.38 \%$ for wholesaler traders, $3.93 \%$ for retail traders.
The supply chain's success rate can be determined by measuring each channel's efficiency level in the supply chain. According to Kurniawan et al. (2014) explains that in the marketing process, it is more efficient if the performance of the marketing agencies involved is also efficient so that all parties will increasingly benefit. One indicator that can measure the level of supply chain efficiency is to use the marketing margin calculation approach.

Marketing margin shows the gap that occurs at the farmer (producer) level with retailers directly related to consumers. In other words, marketing margin implies: (a) the difference in prices paid by consumers and received by producers; and (b) the price of a set of commercial administration services, which is the result of the interaction between the demand and supply of these services (Mubarok et al. 2015).

The following Table 4 presents the value of the marketing margin received by each marketing agency along with the share of the profits received. The marketing channel used is the shortest chain. It can see that the actors in the supply chain who receive the biggest profits are traders of collectors. The marketing chain's length leads to the less efficient performance of the supply chain for cayenne pepper.

Marketing efficiency is an equilibrium condition in which one can use all profitable opportunities. The smaller the price among existing marketing agencies when compared to costs, it can state that the marketing chain runs efficiently (Kustiari, 2017).

The marketing margin analysis results show that the average selling price at the producer (farmer) level of cayenne pepper is $\mathrm{Rp} 13,012.50$, the share of the profits obtained is $41 \%$ of the average price that reaches the consumer, which is Rp31,583.33. As the first marketing agency, collectors received a profit share of $36 \%$, with an average selling price of Rp26,041.67/ kg less packaging and transportation costs of Rp1,529.69, the profit earned by the collectors is Rp11,499.48. The large volume of products purchased by wholesalers causes the capital that must also provide large, accompanied by greater risks that wholesalers must bore, such as the risk of product damage, fluctuating prices, and risks in transportation and distribution. This is a factor in the high selling price or margin set by collectors. 
Table 4. Marketing margin of cayenne pepper, Wongsorejo District, Banyuwangi Regency

\begin{tabular}{|c|c|c|c|c|}
\hline \multirow{2}{*}{ Marketing Institution } & \multirow{2}{*}{ Channel 1} & \multirow{2}{*}{ Channel 2} & \multicolumn{2}{|c|}{ Share } \\
\hline & & & Profit Share & Cost Share \\
\hline Producer & & & $41,20 \%$ & \\
\hline Production cost & 7.925 & 7.925 & & \\
\hline Selling price & $13.012,50$ & $13.012,50$ & & \\
\hline Margin & $5.087,50$ & $5.087,50$ & & \\
\hline Harvesting costs & 500 & 500 & & \\
\hline Advantage & $4.587,50$ & $4.587,50$ & & \\
\hline Collector & & & $36,41 \%$ & \\
\hline Purchase price & & $13.012,50$ & & \\
\hline Selling price & & $26.041,67$ & & \\
\hline Margin & & $13.029,17$ & & \\
\hline Cost (packaging, transportation) & & $1.529,69$ & & $4,84 \%$ \\
\hline Advantage & & $11,499.48$ & & \\
\hline Retailer & & & $15,26 \%$ & \\
\hline Purchase price & & $26.041,67$ & & \\
\hline Selling price & & $31.583,33$ & & \\
\hline Margin & & $5.541,67$ & & \\
\hline Cost (packaging, transportation) & & 723,54 & & $2,29 \%$ \\
\hline Advantage & & $4.818,12$ & & \\
\hline Total Cost & 500 & $2.753,23$ & & $7,13 \%$ \\
\hline Total margin & $5.087,50$ & $23.658,33$ & & \\
\hline Total profit & $4.587,5$ & $20.905,10$ & $92,87 \%$ & \\
\hline
\end{tabular}

Indriani et al. (2020) revealed that, during the harvest season, cayenne pepper production is in high volume and causes this commodity's price to fall, so that many farmers do not harvest the chili product. During this condition, traders and retailers store and dry cayenne pepper for 1-2 weeks. When the price goes up, they then sell the dried cayenne pepper. Kliwon Hidayat (2017) adds that agribusiness risks arise from factors that cannot be predicted and are entirely controlled by farmers. Agribusiness risks are of several types, including: Production and technical uncertainty; Uncertainty of input and price factors; Financial uncertainty; Uncertainty of advanced technology.

Retailers, as the second marketing agency, set an average selling price to consumers of Rp31,583.33 which is reduced by packaging and transportation costs of Rp723.54/kg, get a profit share of $15 \%$ or Rp4,818/ $\mathrm{kg}$. This marketing agency sets the selling price based on the prevailing average market price.

Farmers as producers spend more on labor during the production process, but with a margin of Rp5,087.50 and harvesting cost Rp500, and farmers still get a profit of Rp4,587.50/kg of cayenne pepper. Through several institutions, namely wholesalers and retailers, the marketing chain causes consumers to spend far more money than if they buy in short marketing channels or buy directly from farmers. It can see that the average marketing margin of cayenne pepper from farmers to consumers is $\mathrm{Rp} 18,570.83$.

\section{Managerial Implication}

This study shows that the level of efficiency is not proportional from the perspective of farmers (producers) who get much smaller added value than marketing agencies. This can lead to gaps between actors in the supply chain of cayenne pepper in Wongsorejo District. The number of actors in the cayenne pepper marketing chain also causes the price at the consumer level to be high. There needs to be local government intervention in regulating the marketing of cayenne pepper. One of them is by reactivating the joint role of farmer groups as a medium for providing capital as well as marketing, which can be an alternative to increase the 
bargaining value of farmers and reduce dependence on one marketing agent, or facilitate access to other capital providers, as well as cayenne pepper processing companies.

\section{CONCLUSIONS AND RECOMMENDATIONS}

\section{Conclusions}

The conclusions of this study are: 1) The flow of the cayenne pepper supply chain in Wongsorejo District consists of Agricultural Kiosks and the Government as suppliers; farmers as producers; Collector traders, wholesalers, retailers and market traders as distributors; as well as consumers; 2) The added value obtained by farmers is $\mathrm{Rp} 5,845.83$ / kg, wholesaler of Rp12,849.48 / $\mathrm{kg}$, and retailers of $\mathrm{Rp} 5,323.74$ / $\mathrm{kg}$ with a marketing margin from farmers to consumers of Rp18,750.83/kg; 3) The supply chain of cayenne pepper in Wongsorejo District is classified as efficient, seen from the share of profits that greater than the share of costs.

\section{Recommendations}

This research recommends that can carry out further research on farmers 'efforts to adapt and minimize the risk of environmental uncertainty, as well as the development of cayenne pepper supply chain models in Wongsorejo District with a more efficient chain and can increase farmers' bargaining value, with the role of policymakers. Broader, so that integration is formed between producers and related supporting institutions, such as financial institutions and cayenne pepper processing companies.

\section{ACKNOWLEDGMENTS}

The author would like to thank the Ministry of Research and Technology of Higher Education of the Republic of Indonesia for providing funding support for the implementation of this research.

\section{REFERENCES}

Economy.okezone.com. Sentra Produksi Cabai di Banyuwangi, Lumajang hingga Jember Rusak.https://economy.okezone.com/ $\mathrm{read} / 2020 / 01 / 22 / 320 / 2156570 /$ sentra-produksi- cabai-di-banyuwangi-lumajang-hingga-jemberrusak [14 Sept 2020].

Febriyanti, Affandi MI, Kalsum U. 2017. Analisis finansial dan nilai tambah agroindustri keripik pisang skala umk di Kota Metro. Jurnal IlmuIlmu Agribisnis: Journal of Agribusiness Science (JIIA) 5 (1): 48-56

Felisia, Limijaya A. 2014. Januari. Triple Bottom Line dan Sustainability. https://media.neliti.com/ media/publications/27607-ID-triple-bottomline-dan-sustainability.pdf [2 Sept 2020].

Hayami Y, Kawagoe T, Marooka Y, dan Siregar M.1987. Agricultural Marketing and Processing in Upland Java, A Prospective From Sunda Village. Bogor: The CGPRT.

Hidayat H. 2017. Farmer strategy towards risks in chili agribusiness through informal partnership in maju district siram Village Malang Regency. Agricultural Socio-Economics Journal 17(1): 06-15. https://doi.org/10.21776/ ub.agrise.2017.017.1.2.

Hidayat S, Marimin, Suryani A, Sukardi, Yani M. 2012. Modifikasi metode hayami untuk perhitungan nilai tambah pada rantai pasok agroindustri kelapa sawit. Jurnal Teknologi Industri Pertanian 22 (1): 22-31.

Indriani R, Darma R, Musa Y, Tenriawaru A N, Imran, S. 2020. Product flow pattern at cayyene pepper supply chain. IOP Conf. Series: Earth and EnvironmentalScience486(2020)012003.https:// doi.org/10.1088/1755-1315/486/1/012003.

Karyani T, Renaldi E, Sadeli AH, Utami HN. 2015. Design of supply chain financing model of red chili commodity with structured market orientation. IJABER 13 (7): 6187-6200.

Kementerian Perdagangan Republik Indonesia. 2019. Analisis Perkembangan Harga Bahan Pangan Pokok di Pasar Domestik dan Internasional. Jakarta: Pusat Pengkajian Perdagangan Dalam Negeri Badan Pengkajian dan Pengembangan Perdagangan Kementerian Perdagangan Republik Indonesia.

Kurniawan RD, Suwandari A, Ridjal. 2014. Analisis rantai pasokan (supply chain) komoditas cabai merah besar di Kabupaten Jember. Berkala Ilmiah Pertanian (9): 10-17.

Kustiari R. 2017. Market integration and price formation of chili in Indonesia. International Journal of Sciences: Basic and Applied Research (IJSBAR) 36 (3): 301-319.

Mubarok AA, A Arsyad, dan H Miftah. 2015. 
Analisis nilai tambah dan margin pemasaran pisang menjadi olahan pisang. Jurnal Pertanian 6 (1): 1-14.

Tabloid Sinar Tani. 2018. Cabai Banyuwangi Siap Pasok Ibukota dan Bali Hingga Akhir Tahun. https://tabloidsinartani.com/detail/ indeks/horti/6876-Cabai-Banyuwangi-SiapPasok-Ibukota-dan-Bali-Hingga-AkhirTahun\#: :text=Kabupaten\%20Banyuwangi\%20 memang\%20menjadi\%20salah,DKI\%20Jakarta\%2C\%20Bali\%20hingga\%20Kalimantan. [23 Oct 2020].

Ndiba TAF, Wullur M, Tumade P. 2016. Evaluasi kinerja rantai pasok komoditas cengkeh (studi pada Desa Lalumpe Kabupaten Minahasa). Jurnal EMBA 4 (1): 153-164.

Pujawan IN, Mahendrawathi ER. 2010. Supply Chain Management Edisi Kedua. Surabaya: Guna Widya.

Pujawan IN, Er M. 2017. Supply Chain Management Edisi 3. Yogyakarta : Penerbit Andi.

Saragih AE, Tinaprilla N, Rifin A. 2017. Rantai pasok produk beras di Kecamatan Cibeber, Kabupaten Cianjur. Jurnal Manajemen \& Agribisnis 14 (3): 218-229. https://doi.org/10.17358/jma.14.3.218.
Sondakh N, Rengu JO. 2017. Faktor-faktor yang memengaruhi peningkatan pendapatan usahatani cabai rawit di Kabupaten Minahasa Selatan. Jurnal Bisnis dan Kewirausahaan 13 (2): 74-86. https://doi.org/10.31940/jbk.v13i2.698.

Qashiratuttarafi, Adhi AK, Priatna WB. 2018. Analisis nilai tambah pelaku rantai pasok organisasi Jaringan Madu Hutan Sumbawa (JMHS) Menggunakan Metode Hayami. Jurnal Agribisnis Indonesia 6 (2): 133-148. https://doi. org/10.29244/jai.2018.6.2.133-148.

Lestari S, Abidin Z, Sadar S. 2016. Analisis kinerja rantai pasok dan nilai tambah produk olahan kelompok wanita tani melati di desa tribudisyukur kecamatan kebun Tebu Lampung Barat. Jurnal Ilmu-Ilmu Agribisnis: Journal of Agribusiness Science (JIIA) 4 (1): 24-29.

Wardhono A, Indrawati Y, Qori'ah CG, Nasir MA. 2020. Institutional arrangement for food price stabilization and market distribution system: study of chili commodity in Banyuwangi Regency. E3S Web of Conferences 142, 05006 (2020). https:// doi.org/10.1051/e3sconf/202014205006. 